\title{
Freeboard Monitoring System as an Early Warning System on Railroad Bridge with Solar Cell as Resource Energy
}

\author{
Rizky Arief Qurnianto \\ Railway Building and Track Technology \\ Indonesian Railway Polytechnic \\ Madiun, Indonesia \\ rizkyariefqurnianto@gmail.com \\ Adya Aghastya \\ Railway Building and Track Technology \\ Indonesian Railway Polytechnic \\ Madiun, Indonesia \\ adya@ppi.ac.id
}

\author{
Christiant Anandhitya Tri Mulyanto \\ Railway Building and Track Technology \\ Indonesian Railway Polytechnic \\ Madiun, Indonesia \\ christiantzk@gmail.com \\ Suwandi \\ Railway Building and Track Technology \\ Indonesian Railway Polytechnic \\ Madiun, Indonesia \\ suwandi@ppi.ac.id
}

\begin{abstract}
The bridge is a construction that connects paths that are cut off by rivers, ravines, or construction. One of the requirements of the bridge is freeboard. Safety height is the height measured from the water to the lowest bridge construction. The survey results are still a railroad bridge that does not meet the requirements for security, which is below one meter. The absence of continuous, direct monitoring can cause disruption of travel until an accident can occur when a major flood occurs. The pattern of river water level changes often changes the monitoring of bridges that have the potential for flooding. From the above problems found an alternative solution to the problem, namely using a water level monitoring device that can monitor the water level continuously. The tool will send the results in the form of water level data and provide an early warning when the water level is approaching the bridge or has a dramatic increase in height.
\end{abstract}

Keywords: the bridge, freeboard, high level water, water level monitoring device

\section{INTRODUCTION}

The railroad bridge is one of the railroad infrastructures that serve to connect the line that was cut off due to the river, ravines, valleys, and construction. The railroad bridge is part of the construction of the railroad. Bridge construction is divided into two parts, namely lower construction (substructures) and upper construction (superstructures) under construction on bridges such as pillars, foundations, and abutments.

On the bridge, there is a test to ensure that a completed construction is safe and feasible to pass. One of the bridge testing is guard height. The guard height is the height measured from the river's water level to the lowest girder on the bridge whose distance must be more than one meter [1].

In fact, there is still a high guard height of less than one meter with very high river water discharge. In Fig. 1, there was a flood that almost sank the railroad bridge in Padang and in Gombong 2019. This very high-water discharge will potentially cause a sudden increase in river water and can submerge the railroad bridge. When the railroad bridge is flooded to exceed the height of the railhead, it will directly interfere with train travel activities, and even train stops will interfere with train travel. In bridge construction, a retrofitting rail such as a bent rail will be installed to hold the rails that are stuck on the bridge.

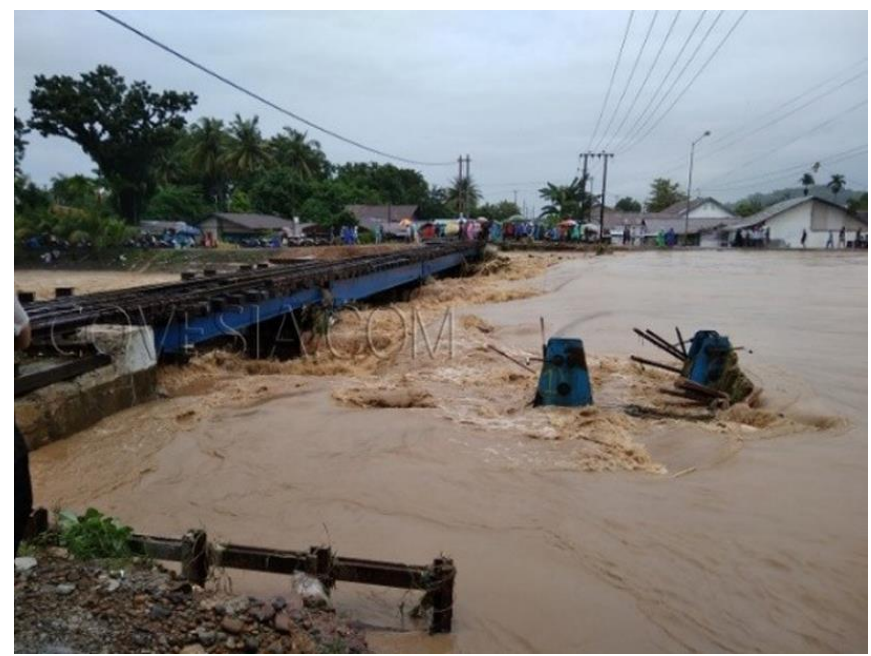

Fig. 1. The railroad bridge is almost flooded.

The absence of early warning when there is a flood in every river that has the potential to flood can endanger the trains that are and will pass. It's referring to things in the field; there needs to be direct and continuous monitoring. The monitoring can use a tool that is able to provide the results of data on the height of distance from river water and early warning when river water has approached the bridge or less than a height of one meter in order to give the first warning to avoid accidents on train travel. 


\section{LITERATURE REVIEW}

This previous research has become one of the writer's references in conducting research so that the writer can enrich the theories used in studying the research conducted. From previous research, the writer did not find the same title as the author's research title. But the authors raised some research as a reference in enriching the study material in the author's research. Here follows the previous research in the form of several journals related to the research conducted by the author, namely as follows:

- A hybrid renewable system based on wind and solar energy coupled with electrical storage: Dynamic simulation and economic assessment.

- Development and evaluation of a new hybrid ammonia fuel cell system with solar energy.

- Techno-economic analysis of hybrid renewable energy system with solar district heating for the net-zero energy community.

\section{A. Railroad}

Railway according to Law number 60 of 2012 concerning railways is a unified system consisting of infrastructure, advice, and human resources as well as norms, criteria, requirements, and procedures for the operation of railroad transportation [1]. Infrastructure is a railway line, a train station, and a train operation facility so that the train can be operated. One of the types of infrastructure is the bridge or wisdom building. The bridge is one of the infrastructures that serve to connect the line that was cut off due to rivers, valleys, ravines, and construction [2].

\section{B. Freeboard}

The guard height is the height measured from the water level to the lowest girder of the railroad bridge. Guard height or freeboard must be above one meter or more [3]. Testing of new high bridge guarding is also included in tests which must be more than one meter like Fig. 2. Measuring height guard using manual methods such as using a meter or using a thread with a stone tied at the end of the yarn [4]. Then the traces of water contained in the yarn are measured with a meter.

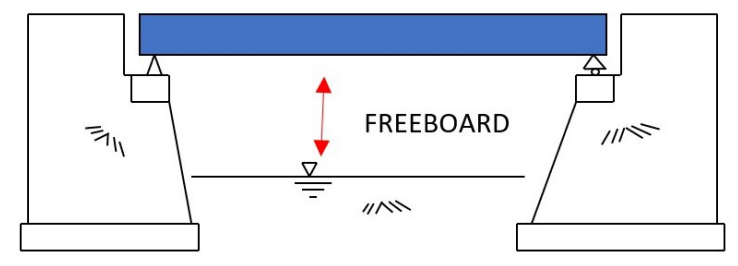

Fig. 2. Freeboard.

\section{The DATA ACQUisition SETUP}

The microcontroller is a functional computer system on a chip. In Fig. 3, case design of monitoring system to direct monitoring can cause disruption of travel until an accident can occur when a major flood occurs

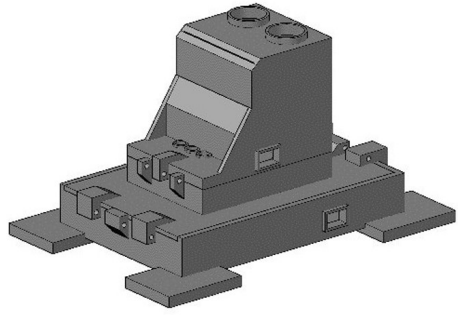

Fig. 3. Case Design of Freeboard Monitoring System.

\section{A. Wemos D1 mini}

Wemos D1 mini is a mini wifi board based on ESP8266 which is claimed to be economical and reliable. This ESP8266 can connect microcontroller devices such as Arduino to the internet network. Wemos D1 mini can do a mini project without using Arduino as a microcontroller because Wemos D1 min can work alone or stand-alone to process each bait code or coding that enters.

\section{B. Ultrasonic Sensor HC-SR04}

Ultrasonic sensor HC-SR04 is a distance measuring sensor that uses ultrasonic waves to detect a distance [5]. The working principle of the sensor is in the transmitter and receiver. At the transmitter's duty is to emit waves and aka received by the receiver when the waves are reflected because there are objects that are exposed to the wave beam. The specification of the distance that can be emitted is $3 \mathrm{~cm}$ - $400 \mathrm{~cm}$, with an accuracy of $3 \mathrm{~mm}$.

\section{Blynk Platform and Thinger.io Platform}

Blynk is a platform that has android application to support the Internet of Things project. This server service has a mobile user environment, both android, and iOS. Thinger is a platform provider that makes it easy to export files from devices connected to this platform.

\section{Solar Panel Cells}

Solar Panel is a medium for changing sunlight that is converted into electricity either directly or indirectly. The solar panel is square and black. Each solar cell is capable of producing a voltage of around $0.45-0.5 \mathrm{~V}$ and an electric current that can be turned around 0.1 Ampere.

\section{THE DATASET}

\section{A. Casing Making}

The casing used uses PLA and ABS filament material. This material was chosen because it considers using iron and wood. PLA and ABS filament has a lightweight and is able to withstand heat temperatures up to $150 \mathrm{C}$ with a melting point of $210 \mathrm{C}$ [1].

1. Part One: The first part has a function for the container of mobile wifi with dimensions of $124 \times 83 \times 20$ $\mathrm{mm}$ with a thickness of $3 \mathrm{~mm}$, and the weight of the casing reaches 47 grams. There are 4 foot-shaped beams with dimensions of $28 \times 28 \times 5 \mathrm{~mm}$ with circular holes with a 
diameter of $26 \mathrm{~mm}$ that serve as magnets to glue the tool to the steel girder. The magnet has dimensions of $\mathrm{d} 25 \times 2 \mathrm{~mm}$.

2. Second Part: The second part is the closing and connection between the first part and the third parts. This section casing has dimensions of $72 \times 52 \times 12 \mathrm{~mm}$ with a thickness of $2 \mathrm{~mm}$ on the wall and base of the casing. The function of this casing is for the laying of PCB components that have been strung together with the Mini D1 Wemos with additional ingredients added using pieces from the breadboard. The weight of this case reaches 24 grams.

3. Part Three: This third part has the closing function of the second part and the placement of the ultrasonic sensor, which has 2 holes with a diameter of $16 \mathrm{~mm}$ with a thickness of $2 \mathrm{~mm}$ per wall. There are 3 small holes measuring $3 \mathrm{~mm}$ that function for the placement of LED lights which become indicator lights. The weight of this section casing reaches 22 grams.

\section{B. Component Assembly}

1. Core Device Assembly: The core device of the height measuring device consists of Wemos D1 mini and PCB. Both of these devices have their respective functions and tasks. Wemos do not have pin legs on 8 pinholes. Wemos is added with male header pins soldered in each pinhole. A 4-pin female header is attached to the PCB for the socket of the jumper cable connected to the sensor. Installation of pins on the PCB in accordance with the printed grooves from the PCB mold. Then Wemos is installed on the socket in the PCB in accordance with the mold of the PCB.

2. Assembling Support Assembling: The HCSR-04 ultrasonic sensor has 4 pins which are used for communication with Wemos which consists of Vcc, Trig, Echo. And Gnd / Vec pin is used as a power input that is connected to $5 \mathrm{~V}$ power on Wemos. The Gnd (Ground) pin is connected to the Socket $G$ on the Wemos which functions as $0 \mathrm{~V}$ or neutral power. The Echo pin is connected to the D2 analog socket on the wos which serves as the signal received from the sensor while the Trig pin is connected to the D1 analog socket which has the task of sending sensor signals.

3. Assembling Enhancements: Assembly between 5 $\mathrm{mm}$ LED lights red, yellow and green. The LED lights have 2 -foot pins, namely the cathode (-) and the anode $(+)$. The pin legs are connected to the mold hole on the PCB by soldering.

\section{How it Works}

This height-measuring device uses Wemos D1 mini for serial communication with sensors and data transmission. The monitoring system uses the blynk platform and thinger.io, which can be monitored online and can be downloaded as data files from the sensor readings. When the core device is connected to the power bank that uses solar cell power, the device automatically turns on but cannot run the system because it is not connected to the internet network that is generated from mobile wireless. The device will be connected to the network specified in the code and will automatically connect if the device and mobile wireless are turned on. When the tool is on, the tool is ready to be installed on the specified bridge. The tool is installed in the lowermost of the bridge superstructure [6].

The ultrasonic sensor will automatically read the water level according to a predetermined time. The device that has been installed on the specified bridge will provide notification on the blynk platform on the smartphone [5]. The notification will show that the device is connected to the internet and is ready to run. Monitoring can be done outside the bridge area that has been installed because the tool has been connected automatically with the internet network. Monitoring can be done at the office or at designated posts. The platform thinger can be opened via the web address http://thinger.io/ which goes directly to the main page of the platform [7] [8]. On the main page, you must log in with an email address that is registered and verified. After a successful login, there will be 4 main menus, namely, dashboard, device, bucket, and statistics. On the device menu, if the device is already running and connected to the internet, there will be a connected sign on the device menu. When the device is connected, monitoring can be done on the dashboard menu. On the dashboard menu can be monitored directly graph up and down from the reading of the tool. Data will be automatically stored in the bucket menu and on that menu data downloads can be made according to the desired day or date.

TABLE I. ACCUMUlation DATA AT EVERY MinUte IN BH 429 ACross BABADAN - MAdiun StATION AUgST, 18TH 2019

\begin{tabular}{|l|l|l|}
\hline No & \multicolumn{1}{|c|}{ Distance (cm) } & \multicolumn{1}{|c|}{ Ts (time) } \\
\hline 1 & 434,717 & $15: 59$ \\
\hline 2 & 433,957 & $16: 00$ \\
\hline 3 & 431,403 & $16: 01$ \\
\hline 4 & 430,025 & $16: 02$ \\
\hline 5 & 431,614 & $16: 03$ \\
\hline 6 & 432,991 & $16: 04$ \\
\hline 7 & 433,442 & $16: 05$ \\
\hline 8 & 434,643 & $16: 06$ \\
\hline 9 & 431,545 & $16: 07$ \\
\hline 10 & 431,819 & $16: 08$ \\
\hline
\end{tabular}

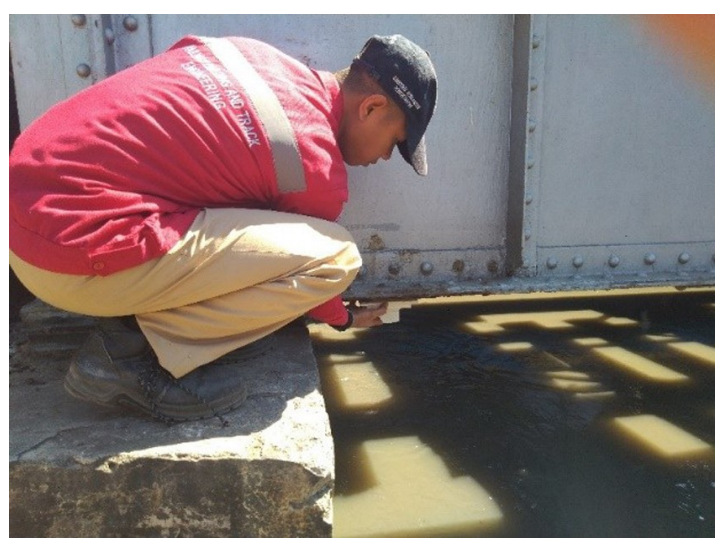

Fig. 4. Installation of Device at $\mathrm{BH} 82$. 
Examples of data reading results (TABLE I) obtained from the bucket menu in the form of data in the form of Microsoft Excel with details of the data are the distance and time when reading by the sensor. In Fig. 4, how to installation of Device to take in under the bridge at BH 82 . Read from the tool shows a number of more than $200 \mathrm{~cm}$, which is considered a safe bridge tool. The tool will give a hazard warning if the distance is less than the minimum range. Minimum range and maximum range are specified in the coding on the core device. The division of conditions is divided into 3 parts, namely:

- Safe is the distance read exceeds the maximum range programmed. (range $\max =200 \mathrm{~cm}$ )

- Warning that the distance read by the sensor is between $100 \mathrm{~cm}-200 \mathrm{~cm}$ or between the minimum and maximum range.

- The danger is that the distance read is less than the minimum range of $100 \mathrm{~cm}$.

In the position of the danger of eating will appear in the form of notifications that appear on the smartphone without having to open the blynk platform first.

\section{CONCLUSIONS}

This research was conducted on a bridge that has a low guard height and a large flood potential, then it can be concluded:

- Measuring the height on the railroad bridge using a microcontroller becomes a means of monitoring water levels which at any time can jeopardize train travel.

- This tool can provide more accurate results and can be monitored remotely with graph data.

\section{A. Suggestion}

From the field situation, many bridges with high guard distance are less than the specified conditions, and there is no means for early warning when sudden floods occur that can immerse or disrupt train travel activities. The suggestions needed for this are as follows.

1. From the results of research for the future, it is necessary to collect data for railroad bridges that have a swift river flow and less guard height.

2. The tool used in the future can be used globally.

\section{REFERENCES}

[1] Government of Republic Indonesia. Regulation Minister of Transportation number 60 of 2012 concerning the Technical Requirements of Railroad Lines (in Indonesian). Republic of Indonesia Gazette in 2007. Jakarta: State Secretariat, 2012.

[2] Government of Republic Indonesia. Regulation Minister of Transportation number 32 of 2011 concerning Standards and Procedures for Maintaining Railway Infrastructure (in Indonesian). Jakarta: State Secretariat, 2011.

[3] Andrianto, Heri. Arduino:Fast Learning and Programming. Informatics (in Indonesian). Bandung, 2015.

[4] Rosyidi, Sri Atmaja P. Railroad Engineering (in Indonesian). Bantul: Civil Engineering of UM Yogyakarta, 2015.
[5] Slamet, Hani. SRF05 Ultrasonic Sensor as Bouncing Motor Vehicle Speed (in Indonesian). Yogyakarta: Electrical Engineering of IST AKPRIND, 2010.

[6] Surakim, H. Railroad Construction and Railroad Travel Safety (in Indonesian). Bandung: Nuansa Cendekia, 2014.

[7] Gunawan. Server and Client Meaning (in Indonesian). http://gugungunawann449.blogspot.com/2017/09/sejaraharduino.html. 2017. Quote on January, 26th 2019.

[8] Sakti, Hari. Sending Distance Data using Ultrasonic Sensors and GSM Shield (in Indonesian). http://www.kodingindonesia.com/pengiriman-data-jarakmenggunakan-sensor-ultrasonik-dan-gsm-shield/. 2016. Indonesian Coding. Quoted on February, 1st 2019. 